\title{
Work and Nature: Collective Health Challenges Towards the Sustainable Development Goals After the COVID-19 Pandemic
}

\author{
Marcelo Amable ${ }^{1, *}$, Rocio Gonzalez Francese ${ }^{1}$, Cecilia Schneider ${ }^{2}$ \\ ${ }^{1}$ Study Group About Work and Environmental Health, Department of Environment and Tourism, National University of Avellaneda, \\ Avellaneda City, Argentina \\ ${ }^{2}$ Department of Social Sciences, National University of Avellaneda, Avellaneda City, Argentina
}

Email address:

maramable@undav.edu.ar (M. Amable), rgonzalezfrancese@undav.edu.ar (R. G. Francese), cschneider@undav.edu.ar (C. Schneider)

${ }^{*}$ Corresponding author

\section{To cite this article:}

Marcelo Amable, Rocio Gonzalez Francese, Cecilia Schneider. Work and Nature: Collective Health Challenges Towards the Sustainable Development Goals After the COVID-19 Pandemic. Journal of Health and Environmental Research. Special Issue: Health and the Environment as a Resource for the Reduction of Social Inequalities in Argentina. Vol. 7, No. 1, 2021, pp. 49-57.

doi: $10.11648 / \mathrm{j}$.jher.20210701.19

Received: January 4, 2021; Accepted: February 20, 2021; Published: March 9, 2021

\begin{abstract}
Work is a central concept to understand social metabolism. Human work is the process that getting the social metabolism that creates those goods necessary for to life. The industrial revolution laid the foundation for an insurmountable contradiction between capitalism and environmental sustainability. The advance of market power over the use of natural resources to sustain globalized lifestyles is responsible for various manifestations of the ecological crisis. As in the rest of the world, in Latin America this type of economic growth has a negative impact on ecosystems in general and on biodiversity in particular. A productive structure that is extractive and intensive of natural resources that not only show its unsustainability, but also its incapability to produce development and well-being. The current COVID-19 pandemic highlights the economic system's vulnerabilities on an unsuspected scale. The SDG issued in 2015, acknowledges the ecological crisis and recognition the impossibility of finding global governance mechanisms with regulatory capacity. The COVID-19 pandemic called into question the economic paradigm perspective on which some of the SDG are based: economic growth and globalization. It is the field of health where the impact of COVID-19 pushes SDG further away. The public health response is limited in the face of the impacts of an epidemic that strikes at the SDG's multiple dimensions. The crisis caused by the COVID-19 pandemic is profound. The SDG are not exempt from that perspective, if they manage to prove themselves as guiding principles for global governance. We argue that the opportunity to find structural solutions with long-term horizons will rise from radical changes in the ways we produce, distribute and consume. Collective health could contribute to the redefinition of the SDG if it faces the challenge of a public health that takes up ecosocial approaches by redefining the social uses of work and nature. The first condition to initiate those structural changes is a progressive de-commodification of life. The second fundamental condition for sustainable welfare is the democratization of social life. Finally, collective health can contribute to redefine the SDG if faces the challenge of a public health that takes up eco-social approaches.
\end{abstract}

Keywords: Collective Health, Environmental Health, Occupational Health, SDG, COVID-19

\section{Introduction}

Homo sapiens evolved by transforming the habitat in which they settled adapting it to their historical living conditions. While achieving that goal more or less erratically, they were also altering their own human nature. Humanity's dialectical relationship with nature is a consequence of its dependence on nature to guarantee life. But human life is not spontaneous; it needs to assert itself in social relations capable of ensuring its subsistence.

Human work as a project, that is to say, an idea that push forwards the social practices that are necessary to achieve 
certain goals, is the process that in different social formations allows getting the necessary natural resources to sustain life. The social metabolism that creates those goods slowly printed the social goals that characterized each historic period [1].

The industrial revolution which allowed the consolidation of the capitalist production system generated the first significant changes in the social metabolism. Not only because of the revolutionary innovations in the fields of energy and technology, but the social relations of production that set in motion. Towards the end of the 19th century the production of goods was consolidated through a social and cultural transformation that placed the market as the exclusive regulatory form for the behavior of economic agents. The commodification of the factors of production, labour and nature, laid the foundation for an insurmountable contradiction between capitalism and environmental sustainability.

In the last decades of the 20th century, once again, the free market expanded pushing borders to tie the production of commodities to the international financial system. As the production of goods and services took root in a globalised and highly financialised capitalism, the ecological crisis began to manifest itself through some signs such as the weakening of the ozone layer or climate change.

The Sustainable Development Goals (SDG) issued in 2015 , expressed a double recognition by the international community [2]. On the one hand, it acknowledges the ecological crisis, at least in one of its most peremptory dimensions: global warming. On the other, the motion to use multilateral agreements as a method to achieve the posed goals conceded the impossibility of finding global governance mechanisms with regulatory capacity to have countries comply with them.

In this context, when the year 2019 was coming to an end, a new epidemic prompt by an unknown virus arose, the SARS-CoV-2, transforming itself in a couple of months in the COVID-19 pandemic, whose scope and repercussions are still impossible to predict. However, the damage cause after ten months of a worldwide pandemic is unprecedented for humanity. First of all, there is the health dimension: deaths, infected population, sequelae among survivors, health services for population care, expenditures on patient care and preventive measures, customization of health care systems, investment in and care of health personnel and health equipment, etc. Then there is also a economic dimension: drops in economic growth in all countries and simultaneously, the impoverishment of their economies, increasing unemployment and labour informality, precarisation of employment and increasing social inequalities, instability of economic activities, etc.

In this sense, we argue that any programs made prior to the pandemic should be reviewed. The SDG set for 2030 need to be adjusted because not only there has been a regression during the year 2020, but also because it is difficult to predict when certain conditions for production and consumption will be restored. The very legitimacy of the SDG, that is, the deadlines for their implementation, became a threat to their validity. The time to overcome obstacles will depend on the radical nature of their solutions.

\section{Commodification of Work and Nature}

Human life can only subsist in a natural environment. Although due to the various social mediations of complex societies it is difficult to perceive it, all of them carry out activities in order to appropriate natural products for their own use. It could be said that there is no ecological vacuum for social life but rather a need to appropriate the materials provided by nature, defining nature as that which exists and reproduces itself independently of human activity [3].

Human societies produce and reproduce their material conditions of existence from processes of social metabolism. This process is a necessary condition for the sustenance of life that acquires different forms according to defining historical features. The appropriation, transformation, circulation, consumption and excretion of materials and energy that come from the natural world, take different forms that shaped the history of humanity [4].

Work is a central category for understanding social metabolism because it articulates the moment of appropriation of nature with the rest of the necessary moments for social life. Work is the act by which humans make a fragment of matter or energy, travel from the natural space into the social space [5]. But human work possesses distinctive characteristics of the way other animal species also appropriate natural resources. The importance lies in the fact that human work is conscious and deliberate; it is a deliberate action guided by a means-end rationality that defines not only the ways of working but the world as we know it.

During the 19th century the commodification of labour was consolidated. This happened to such extent that although the projection of work continued to be the human conscience, the unit conception-execution was disjointed by the emergence of social sectors that took on a new social division of labour. A long process of economic, political and social transformations was necessary to transform labour into a commodity. "La producción es integración entre el humano y la naturaleza, para que este proceso se organice a través de un mecanismo autoregulador de trueque e intercambio, el hombre y la naturaleza deberán ser atraídos a su órbita, deberán quedar sujetos a la oferta y la demanda, es decir, deberán ser tratados como mercancías, como bienes producidos para la venta" [6].

While production could theoretically be organized in this way, by buying and selling labour-power, it was omitted that leaving its use to the fate of the market meant its own annihilation. "Si se permite que el mecanismo de mercado fuese el único director del destino de los seres humanos y de su entorno natural, incluso de la cantidad y el uso del poder de compra, se demolería la sociedad. Al disponer de la fuerza de trabajo de una persona, el sistema dispondría incidentalmente de la entidad física, psicológica y moral que 
es el "humano". Privados de la cobertura protectora de las instituciones culturales, los seres humanos perecerían por los efectos del sistema para social" [6]. Social protection is imposed on economic rationality as an external limit to the system of production. Market boundaries are defined by the democratic assessment that puts the health and well-being of people before the profitability of capital.

In the face of expansion and subordination to market mechanisms, the dangers to humans and nature cannot be clearly differentiated. Just as labour is part of life, land is part of that nature that has not been produced by human beings. Yet both are introduced into capitalist production in its mercantile form subordinating the substance of society itself to the laws of the market. It is necessary for democracies to create institutions with the capacity to regulate and limit this process of mercantile expansion in order to preserve life and nature from the dangers of "la explotación del vigor físico del trabajador, la destrucción de la vida familiar, la devastación de las vecindades, la deforestación de los bosques, la contaminación de los ríos, el deterioro de la calidad de las artesanías, la destrucción de las costumbres, la degradación general de la existencia, incluidas la vivienda y las artes, así como las innumerables formas de la vida privadas y pública que no afectan a las ganancia" [7].

The subordination of the planet's surface to the needs of industrial societies has been a long social and economic process during the 19th century, marked by free trade. The globalization that emerged in the last decades of the 20th century sought to maximize the free movement of capital in each country and at the international level. Liberalization of financial markets expanded without any regulation to new markets, as was the case of raw materials. The emergence of the stock market quotation for the so-called commodities crowned the use of nature as a source of speculative income.

Other manifestations of this mercantilist trend could also be mentioned, for example, in the carbon markets where greenhouse gas emission rights are traded, or in the erratic proposals aimed at Latin American countries that pose the swap of foreign debt for environmental policies. The advance of market power over the speculative use of natural resources to sustain globalised lifestyles, revealed its incapacity as a regulatory mechanism for the sustainable use of natural resources, and it only spawned multiple manifestations of an unprecedented ecological crisis.

The development of the free market without any restrictions to protect essential democratic and cultural values, conditioned the beginning of the 21 st century with a sustained increase in social inequalities, the weakening of the world of labour that made the living conditions of workers precarious and an ecological crisis of alarming dimensions. "La crisis ambiental se suma a la económica y social, y se expresa, entre otras manifestaciones, en la destrucción de los recursos naturales, la contaminación de las aguas, la tierra y la atmósfera, la reducción de la biodiversidad y la pérdida de los bienes comunes globales" [8]. Among the most pressing expressions of the crisis is global warming, which has required the concern and consideration of the international community. After several multilateral initiatives, the Sustainable Development Goals 2030 were posed as a comprehensive plan to begin a new transformation of the capitalist production system towards a horizon of sustainability. However, the COVID-19 pandemic forces us to rethink not only these goals, but the very paradigm that supports them.

\section{The SDG and the COVID-19 Pandemic}

There is a growing consensus that this economic development led to a new geological period called the Anthropocene, in which human action is the main driving force behind the changes produced in the biosphere, even exceeding the safety thresholds for human life [3].

As in the rest of the world, in Latin America this type of economic growth has a negative impact on ecosystems in general and on biodiversity in particular. It is estimated that biodiversity in the region has declined by $89 \%$ among 689 species, representing the largest decline in the world [2]. Another aspects derived from the economic model are deforestation, changes in the use of land and agrochemicals with serious consequences for human health and ecosystems [9]. The region has been a net exporter of biomass, fossil fuels and minerals since the 1970s [10]. A productive structure that is extractive and intensive of natural resources that not only show its unsustainability, but also its incapability to produce development and well-being.

The current COVID-19 pandemic highlights the economic system's vulnerabilities on an unsuspected scale. The reason is twofold.

In the first place, the emergence of the epidemic by contagion of the SARS-CoV-2 virus is in the very foundations of a way of life that needs to destroy natural ecosystems in order to be sustained: either through changes in land use, due to urbanization processes that have no limits, or through a model of industrialized mining-farminglivestock production that supports globalised forms of consumption. The appropriation of primeval forests by the extension of land commodification implies deforestation and destruction of diverse biomes. The lost of biodiversity in enormous extensions of land facilitates that previously locked pathogens spread into livestock and local communities [11].

Regardless of the specific causality that facilitated the adaptation of SARS-CoV-2 into a mammal that could have acted as a vector to humans, the causes of the pandemic are related to a commoditization process that subordinates ecosocial dynamics. The global increase of infectious diseases in recent decades, as well as the recurrent appearance of new viruses, leads us to point out, precisely, the definitive role of capitalism on the widely publicized zoonotic epidemics. At least four epidemics have occurred worldwide since the 1980s (Ebola, SARS, MERS and now COVID-19) [12]. The epidemics will not be understood if they continue to be 
treated as isolated episodes, it is already impossible to elude the structural causes behind unknown viruses.

Secondly, the economic crisis at a global level has caused the largest drop in GDP since the Second World War (-5.2\%) and according to the International Monetary Fund, at the end of this year the drop would reach $3 \%$, which would account as the worst recession since the Great Depression [13]. In addition, the crisis has a new characteristic: it occurs simultaneously in most countries (although the impact on each of them is different) [11]. At the beginning of 2020, Latin America entered into an economic recession with a $1.5 \%$ drop in its GDP compared to the previous year and a projected reduction of $9.1 \%$ for the whole year [11]. The crisis is affecting international trade in a notorious way: in the first quarter of 2020 it fell by $17 \%$ and it is expected that by the end of the year the reduction will be $15 \%$ [2]. A large part of this decrease in international trade is due to the decline in demand for primary products and the fall in their prices [9], which has a direct impact on economic growth in the region.

The consequences of the economic crisis resulting from the pandemic are transferred to the conditions and quality of life of the population. In almost all Latin American countries there is an increase in unemployment as well as, in some of them, a lower proportion of informal work (due to confinement measures to prevent the epidemic). Estimations show that the poverty rate will increase by a $7.1 \%$ in 2020 , that is, it will reach $37.3 \%$, while extreme poverty will increase by $4.5 \%$, reaching $15.5 \%$ of the population [14]. The Latin American population in a situation of poverty would reach a total of 231 million (45 million of new poor in 2020) and 96 million people in extreme poverty ( 28 million more this year) [14].

The COVID-19 pandemic called into question the economic paradigm perspective on which some of the SDG are based: economic growth and globalization. For example, goals such as the End of Poverty (in its target 1.1); or Decent Work and Economic Growth (in its target 8.1); explicitly include achieving sustained economic growth per capita over time. On the other hand, a conception of globalised free trade is deployed as a strategy to reach some of the posed goals. For example, it supports the commodification of water (target 6.1); promotes the agribusiness model through global markets (target 2.b); or encourages a universal multilateral trading system that increases exports and facilitates duty-free market access in line with World Trade Organization guidelines (target 17.10; 11 and 12) [15]. According to one of the first studies to review the SDG after the emergence of the pandemic, two-thirds of them are unlikely to be achieve. And some may even be counterproductive by amplifying problems: $10 \%$ of the SDG targets could worsen the impacts of future pandemics [16].

It is the field of health where the impact of COVID-19 pushes SDG further away. Social inequality in Latin America, characterized by socio-economic, class, gender, ethnic-racial, territorial and migration inequities, has done nothing but gained visibility with the pandemic, and at the same time, it has amplified its consequences. "Las desigualdades en diferentes dimensiones - como el derecho a la educación y a la salud de calidad, a una nutrición suficiente y adecuada, al acceso a infraestructura básica (agua potable y saneamiento) y a las tecnologías de la información y las comunicaciones, el derecho al trabajo decente y a la protección social—no solo han exacerbado la vulnerabilidad y el impacto de la pandemia en ciertos grupos poblacionales, sino que también dificultarían la senda de reconstrucción" [15]. The Economic Commission for Latin America and the Caribbean also projects an increase in income inequality for the year 2020 (an increase in the Gini Coefficient up to $7.8 \%$ ), which implies a regression to values of the 2000s [17]. And in particular, these inequalities are also expressed in the coverage of health systems, their access and results of care.

For example, it has been pointed out that in the United Kingdom the mortality rates of COVID-19 according to the level of deprivation; show that the more disadvantaged the area, the higher the mortality. However, these inequities had been expressed on processes of health inequalities for decades: "una desaceleración en el aumento de la esperanza de vida general, un aumento continuo de las desigualdades en la esperanza de vida entre zonas más y menos desfavorecidas y una disminución en la esperanza de vida de las mujeres en las zonas más desfavorecidas de Londres" [18]. The pandemic affects people acting over existing inequalities either rooted in personal characteristics (race, ethnicity and social class), territory or place of residence and between countries (according to wealth and inequality). "Estos sistemas afectan la exposición al virus (por ejemplo, hacinamiento, densidad de población, exposiciones laborales), afectan la probabilidad de infectarse (factores estresantes y condiciones de salud subyacentes) y afectan la gravedad y la fatalidad de la enfermedad entre los infectados (enfermedades crónicas subyacentes, acceso a la atención de calidad)" [19].

Finally, the social forms of precarious work during the last decades showed market's limits to sustain the dignity of life. One of the first measures to control the epidemic in each country was to restrict the movement of people, allowing only those who perform essential tasks to work [20]. However, staying at home working is a luxury for those who first have a formal job, and secondly, are inserted in general economic activities of the service sector with a certain level of technology [11]. In short, the lower people's income, the less likely they are to have jobs in which it is possible to work from home [19]. This reflects the situation of $54 \%$ of Latin American workers currently in informal jobs, a reality that particularly affects women [21]. It was also necessary to complement the health scope of these measures with social support policies to guarantee the income of these workers because the lower the socioeconomic position, the greater the social, economic and health vulnerability [22]. The result in the region was clear: the capacity of these sectors to follow preventive and control measures was very limited. The precarization of labour during decades of deregulation and commodification of employment has only increased the 
vulnerability "the ways of life of ordinary people" to face the pandemic.

The SDG demand cross-cutting and intersectional policies to achieve development that improves the well-being of the population in a fair and dignified manner, even though there are no explicit goals for the reduction of social inequalities in health [23]. The pandemic has revealed the contradictions of the economic and political structures that produce social inequalities. The public health response is limited in the face of the impacts of an epidemic that strikes at the SDG's multiple dimensions [24]. The challenge for a sustainable development will be to go beyond the limits of rapid and sectorial responses.

\section{Challenges for a Sustainable Well-being}

The development model promoted by global and financial capitalism has proven to be incapable of satisfying the social needs of the population in an equitable and environmentally sustainable manner. In Latin America, as in many other countries including industrialized ones, the pandemic has exacerbated existing problems of social and environmental inequalities. In a region where 8 out of 10 people belong to vulnerable socio-economic stratum, the economy has been showing a slowdown in growth since 2014 [18]. The extent of the pandemic's social, health and economic costs will continue to show during 2021 in a context of slow economic recovery.

The overcoming of other types of globalised crises such as the international financial crisis of 2008, teaches us that the global status quo's capacity to create partial solutions socializing its costs, is excessive and has no transcendental social and political repercussions. The crisis caused by the COVID-19 pandemic is profound. The opportunity to find structural solutions with long-term horizons will rise from radical changes in the ways we produce, distribute and consume.

The SDG are not exempt from that perspective, if they manage to prove themselves as guiding principles for global governance. However, the SDG's necessary revision must wisely resolve the tension caused by the urgency of global warming and the slow pace of the necessary transformations to achieve the goals.

\subsection{Decommodification of Life}

The first condition to initiate those structural changes is a progressive de-commodification of labour and nature. The COVID-19 pandemic challenged the core of the global economy's cultural matrix: the self-regulating market. The State has had to strengthen its various intervention capacities to safeguard not only the health of the population but also economic activity [21]. Different countries implemented sets of intervention measures in order to: guarantee the income of people who could not work or who got infected with SARSCoV-2 while working; determine who could work by defining essential tasks; subsidized directly and indirectly the small and medium size sector or even transnational companies in the face of falling consumption; expand public expenditure to help health systems that are in a state of exhaustion after years of neoliberal adjustment, with the corresponding public debt to cover this expenditure; redirect the production of certain industries towards the provision of health supplies; restrict trade, travel and people's mobility, among others.

The pandemic showed that lacking social protection policies results in enormous health costs. Protecting the working population's income should be a first step in the event of unemployment [23]. But this protection must be extended in terms of rights and coverage in order to create equitable and dignified living conditions. We need universal, redistributive and solidarity-based policies that guarantee protection against labour market risks. The commodification of labour proved to be incapable of providing the necessary resources to satisfy individual and collective needs. Just as there is an energy transition, we must begin to consider a labour transition. Work must progressively recover its autonomy dimension, oriented towards the production of goods for common use and the reproduction of a dignified life.

The same orientation should guide the political regulation of nature: it can no longer be subordinated to the private use of property and the individual usufruct of its exploitation. The social protection movement should attain ways of preserving and protecting nature from the risks of the selfregulating market. Even more so in Latin American countries whose productive structures are concentrated in sector intensive in the use of natural resources, which also are their main sources of foreign exchange. Recurrent zoonotic diseases are an expression of the way we invade unexplored ecosystems, making it easier for unknown pathogens to increase the risk of diseases. Decommodifying nature would make it possible, for example, to readjust its use according to its health consequences. "La apropiación del entorno natural de la sociedad implica un hecho político que lleva impresas las características del poder y de quienes lo ejercen" [10]. The sustainable development model needed for the region requires redefining the ways of appropriation and consumption of natural resources.

The pandemic revealed the need for a change in the development model, allowed us to glimpse the delegitimization of the free market's cultural matrix and left behind an economic growth crisis of enormous dimensions. The way out of this crisis should be to refocus production and labour towards the resolution of human needs in order to achieve sustainability with distribution of well-being. However, a new cultural matrix requires common and public spaces for the definition of our living conditions.

\subsection{Convivial Democracies}

The second fundamental condition for sustainable welfare is the democratization of social life. As a reflection of the market, democracy became reabsorbed into its instrumental 
procedures clearing the way for a pragmatic rationality in the exercise of power. The economic crisis is nothing more than a manifestation of the political crisis, of a representative and delegative democracy that instead of finding new institutional forms for the resolution of multiple conflicts of interests, neutralizes them by emptying the public and common spaces of argumentation.

Democratic institutional structures must channel the production and satisfaction of human needs. It is no less than the principle of social protection what has been regulating and limiting market expansion, with the aim of preserving the health of workers through labour legislation, or natural life through environmental legislation. Democracy must provide the ethical and political dimension of the environment in a perspective of environmental justice and equitable development of well-being. The challenge is to create new spaces of democratic legitimacy at the three levels of the power conglomerate: international, national and territorial.

The SDGs are a positive aspect of international multilateralism that have prompted enough consensuses for their enunciation, but at the same time, suffer from a governance deficit in the absence of institutional mechanisms that control their development and compensate for efforts and imbalances. The same characteristics of ambiguity and contradiction in global governance can be observed in the international reactions to the pandemic. National strategies that seek to contain community transmission within national borders persist, whereas an international cooperation strategy could be much more efficient in controlling the pandemic [25]. Or Mexico's important initiative to prevent speculation on medical supplies in the midst of the pandemic, that led to the UN's General Assembly Resolution 74/274, or the COVAX initiative to ensure equitable access to a potential vaccine. Nevertheless, while writing this article, many of the signatory countries to those agreements have implemented Advance Market Commitments that allow high-income countries to secure 2.2 billion doses, upper-middle-income countries 544 million, and lower-middle-income countries 740 million. While these countries will be able to vaccinate their population several times, only $20 \%$ of the population in low-income countries will be able to do so [26].

Multilateralism as a strategy to defend common good faces a particular challenge regarding the sustainability of welfare: the control of transnational corporations. Globally, these companies account for $70 \%$ of trade, $55 \%$ of exports, $28 \%$ of GDP and $23 \%$ of employment [27]. A globalised economy could not be structured without transnational companies and their planned outsourcing and offshoring. These companies undoubtedly have an influence on the formulation of international and national public policies (many of them represent an economic volume greater than the GDP of some countries). The impact that these transnationals have on the environment requires having their voices democratically counterbalanced by the multiple voices that express the common good.

International cooperation must evolve towards a strengthening of control mechanisms and citizen empowerment. The recent enactment of the Escazú Agreement in Latin America could be a new opportunity in this regard. The Agreement aims to recover fundamental democratic principles to reverse inequality and the culture of privilege rooted in the region, through transparency and environmental information, participation in environmental decision-making and access to justice [28]. It is opportunism or opportunity? That will depend on the rectifications needed to expand democratic systems.

During the pandemic national states have met the high demands for health care and prevention, reconverting, reorienting and adding resources on a large scale; including coordinating the capacities of the private sector. At the same time the management of the isolation or quarantine, showed the temporal limits of an adequate health measure, but which requires political and social consensus beyond instrumental reasoning. Western democracies, to a large extent, revealed their inability to achieve collective consensus beyond the corporative ones. The challenge to change democracies at the national level has a new reason: public health.

The pandemic implied great fiscal efforts, as we said, to strengthen the health sector, as well as to guarantee people's income and employment or the productive capacity of enterprises. The consequence has been an increase in public debt in most countries: it is estimated that in central economies it has been $9.3 \%$ of their GDP, but in Latin American countries this proportion would be of $55.3 \%$ [11]. The collective efforts and sacrifices that will have to be made to pay these public debts require institutional mechanisms that guarantee equity. For example, tax collection in the region is $50 \%$ regressive indirect taxes, while personal income taxes are $2.3 \%$ of GDP (in OECD countries it is $8.3 \%$ ) [2]. Only by improving democratic institutions will it be possible to constitute or consolidate States with universal social policies and distribution of public goods that guarantee equality.

Finally, democratic institutional forms must be adapted to territorial representation. Political ecology has long highlighted the need to identify the territory at its different scales, as the unit upon which policies and institutions should come together in order to strengthen the collaborative capacities for the resolution of public issues. Sustainability needs to deepen a vision that complements equality and democracy with development. The regional diverse sociocultural compositions that pleat in the territory express appreciations more supportive with all forms of life. Democratic spaces for a convivial reconstruction of society should facilitate the imposition of boundaries to economy expansion through mercantilization. What Ivan Illich called "areas of community" or commons [29]. Is possible that in the near future, democratic systems may have to compete by proving their effectiveness with other political systems, whose many tendencies to restrict individual and social rights were visible even before the pandemic: be they autocratic, one-party and/or plutocratic republicans. The elimination of social inequalities in health should be a criterion for assessing the sustainable well-being promoted by such 
political systems.

\subsection{Invigorating Collective Health}

The health of the population is inseparable from the political, economic and social system of a region, country or territory, because it is a consequence of the development type that prevails there. The process of health-disease, as well as mortality levels, are the result of the way society appropriates nature, exploits it, transforms it and distributes its benefits, in order to sustain a certain way of life. Collective health can contribute to redefine the SDG if faces the challenge of a public health that takes up eco-social approaches. Since before the pandemic, collective health has pointed out various aspects that are relevant to understanding and intervening in the health-environment relationship. The following are three characteristics that should be display in the post-pandemic field of collective health.

The first is the importance of ecological knowledge in health. Collective health has traditionally considered the social and environmental dimension. The profile of the health-disease process of a specific population is understood in relation to the ecological, social and economic-occupational system in which it is inserted. Even epidemiology, as one of the disciplines in the field of public health, has been rooted in an ecological conception of disease since its origins, describing and explaining health-disease processes from a biological, ecological, economical and political perspective. And although it has not been the most relevant trend for some decades, the truth is that epidemiology must be a social study that includes the observation of the population and its socioeconomic and environmental reality.

The pandemic showed that it is necessary to take the field of human health in an ecosystem context, that is, to insert the state of health-disease in a complex, adaptive and dynamic interrelationship unit of functioning with the rest of living beings and the physical environment in which is based. Assume the complexity of biological and social phenomena in their multiple interrelations and determinations of different interpretative levels. The observation and analysis of these interrelations is a theoretical and methodological challenge. But the integration of ecology into the field of human health to build epidemiological ecosystems, will allow a holistic understanding of particular problems, such as zoonosis, in their specific, ecological, territorial and social contexts, such as land and resource use [30].

The second characteristic that drives collective health is transdisciplinary knowledge and intervention. The public health in general and epidemiology in particular, must take on the study of the dialectic relationship between the natural and the social because conceptualizing health-disease as a historical, social and ecological process However, these disciplines are not enough. Public health is becoming a complex field that must understand social determinations in their interrelationship with the environment, including both life in its various manifestations and the characteristics of the various natural ecosystems components. A field of knowledge for action, that combines medicine and psychology with social epidemiology and sociology, but also tries to integrate ecology, biology, climatology, ethology, entomology, etc. Although it is still difficult and unknown how to systematically integrate and analyses this knowledge, it is part of collective health's challenge [31].

The pandemic raised the need for an orientation of public health stripped of individualistic, technocratic and curative perspectives, towards a more integrated vision of preventive aspects based on interdisciplinary work. Therefore, the way of producing knowledge must impact on care policies. The model of care that emphasizes biomedicine, hospitals and specialized services, technology and the mass use of medicines [32], must be redirected towards an interdisciplinary, preventive and social participation model.

Finally, the political steering of public health must be strengthened. Social transformation requires strong public health, capable of guiding society and taking responsibility for that leadership. Population's health depends on public health, which must "mejorar la salud laboral y ambiental, construir una potente red de vigilancia epidemiológica, desarrollar la participación comunitaria, o planificar intervenciones a largo plazo para mejorar la salud y aumentar la equidad" [21]. However, the lack of public health infrastructure, inadequate health systems, informal economies and living and working conditions made it impossible in many countries to sustain even the most basic recommendations for personal hygiene and social distancing during the pandemic [20]. The expansion of neoliberalism together with its policies of social austerity, with cuts in public funds for health care and public health services, has been one of the factors that contributed to the pandemic's impact on the population's well-being [13]. The decentralization of these public policies particularly showed the limited and unequal power to address them in a coordinated and effective manner. National states are the ones that took the initiatives to guarantee coherence and equity in the management of epidemics.

Conducive conditions to a positive response to the pandemic include: strong and mature health and social systems, and a comprehensive strategy to attack the epidemic [13]. Public health, in the near future, must take the lead in broadening and deepening collective interventions not only in the health system but also in the provision of social services. Now is the time to bolster universal health services by strengthening the leadership capacity of national authorities, and lower levels, on health system governance. Public health stewardship over universal social and health policies must be asserted in a collective will for change towards sustainable well-being. But building that will is another challenge.

\section{Conclusions}

The human life is not spontaneous. Human work is the process that getting the social metabolism that creates those goods necessary for to life. The industrial revolution laid the foundation for an insurmountable contradiction between 
capitalism and environmental sustainability.

The SDG issued in 2015, acknowledges the ecological crisis and recognition the impossibility of finding global governance mechanisms with regulatory capacity. In this context, the COVID-19 pandemic, whose scope and repercussions are still impossible to predict, the SDG set for 2030 need to be adjusted.

The subordination of the planet's surface to the needs of industrial societies has been a long social and economic process during the 19th century, marked by free trade. The globalization that emerged in the last decades of the 20th century sought to maximize the free movement of capital in each country and at the international level. Liberalization of financial markets expanded without any regulation to new markets, as was the case of raw materials. The emergence of the stock market quotation for the so-called commodities crowned the use of nature as a source of speculative income.

As in the rest of the world, in Latin America this type of economic growth has a negative impact on ecosystems in general and on biodiversity in particular. A productive structure that is extractive and intensive of natural resources that not only show its unsustainability, but also its incapability to produce development and well-being. The current COVID-19 pandemic highlights the economic system's vulnerabilities on an unsuspected scale.

The COVID-19 pandemic called into question the economic paradigm perspective on which some of the SDG are based: economic growth and globalization. It is the field of health where the impact of COVID-19 pushes SDG further away. The public health response is limited in the face of the impacts of an epidemic that strikes at the SDG's multiple dimensions. The crisis caused by the COVID-19 pandemic is profound. The SDG are not exempt from that perspective, if they manage to prove themselves as guiding principles for global governance.

We argue that the opportunity to find structural solutions with long-term horizons will rise from radical changes in the ways we produce, distribute and consume. The first condition to initiate those structural changes is a progressive decommodification of life. On the one hand, the decommodification of labour must progressively recover the autonomy dimension, oriented towards the production of goods for common use and the reproduction of a dignified life. On the order hand, de-commodifying nature would make possible, for example, to readjust its use according to its health consequences. The second fundamental condition for sustainable welfare is the democratization of social life. The economic crisis is nothing more than a manifestation of the political crisis and democratic institutional structures must channel the production and satisfaction of human needs. The challenge is to create new spaces of democratic legitimacy at the three levels of the power conglomerate: international, national and territorial. Finally, collective health can contribute to redefine the SDG if faces the challenge of a public health that takes up eco-social approaches. The pandemic showed that it is necessary to take the field of human health in an ecosystem context, that is, to insert the state of health-disease in a complex, adaptive and dynamic interrelationship unit of functioning with the rest of living beings and the physical environment in which is based. Now is the time to bolster public health by strengthening the leadership capacity of national authorities, and lower levels, on health system governance.

\section{References}

[1] Marx, K. Chapter V. Work process and valorization process. The Capital, Volume I. Buenos Aires: Ed. Cartago, 1956. P. 147-54.

[2] Economic Commission for Latin America and the Caribbean (CEPAL), Building a new future: a transformative recovery with equality and sustainability (LC/SES. 38/3-P/Rev. 1), Santiago, 2020.

[3] Will Steffen, Paul J. Crutzen, and John R. McNeill "The Anthropocene: Are Humans Today Unquestionable The Great Forces of Nature?" AMBIO: A Journal of the Human Environment 36 (8), 614-621, (December 1, 2007). https://doi.org/10.1579/0044-

7447(2007)36[614:TAAHNOíritu2.0.CO;2.

[4] Toledo VM, González de Molina M. (2007) Social metabolism. In Garrido F, González Molina M, Serrano JL and Solana JL (Eds.) The ecological paradigm in the social sciences. Barcelona: Icaria.

[5] Braverman H. Reading 5. Work and labor force (Page 12939). In: Toharia L (Comp.). The labor market: theories and applications. Selected readings. Madrid: Alianza Editorial, 2005.

[6] Polanyi K. Ch. XI. Man, nature and the productive organization (Page 185-188). The Great Transformation. Political and economic origins of our time. México: FCE; 2003.

[7] Polanyi K. Cap. SAW. Self-regulated market and fictitious merchandise (Page 123). The Great Transformation. Political and economic origins of our time. Mexico: FCE; 2003.

[8] Polanyi K. Cap. I. The economic fallacy (Page 82). The livelihood of Man. Barcelona: Mondadori; 1994

[9] Economic Commission for Latin America and the Caribbean (CEPAL) Special Report $\mathrm{N}^{\circ} 1$ Latin America and the Caribbean on the COVID-19 pandemic. Economic and social effects April 3, 2020.

[10] Gligo N. and others, The environmental tragedy of Latin America and the Caribbean, CEPAL Books, $\mathrm{N}{ }^{\circ} 161$ (LC/PUB. 2020/11-P), Santiago, Economic Commission for Latin America and the Caribbean (CEPAL), 2020.

[11] Economic Commission for Latin America and the Caribbean $(C E P A L)$, Economic Survey of Latin America and the Caribbean, 2020 (LC/PUB. 2020/12-P), Santiago, 2020.

[12] Rob Wallace "The agri-food business would put millions of lives at risk." Interview with Rob Wallace 03/28/2020 Source: Marx21, March 11, 2020, https://www.marx21.de/coronavirus-agribusiness-would-riskmillions-of-deaths/. 
[13] Navarro V. The Consequences of Neoliberalism in the Current Pandemic International Journal of Health Services 2020, Vol. 50 (3) 271-275 DOI: 10.1177/0020731420925449.

[14] FMI World Economic Outlook, April 2020: The Great Lockdown April 2020 https://www.imf.org/en/Publications/WEO/Issues/2020/04/14/ weo-april-2020.

[15] Economic Commission for Latin America and the Caribbean (CEPAL) and the Pan American Health Organization (PAHO). Health and the economy: a necessary convergence to face COVID-19 and return to the path towards sustainable development in Latin America and the Caribbean. July 30, 2020.

[16] ONU https://www.un.org/sustainabledevelopment/es/poverty/.

[17] Naiddo R, Fisher B. Reset Sustainable Development Goals for a pandemic world. Nature 583, 198-201 (2020) doi: https://doi.org/10.1038/d41586-020-01999-x 6 de julio 2020.

[18] ECLAC Economic Commission for Latin America and the Caribbean $(C E P A L)$, Reconstruction and transformation with equality and sustainability in Latin America and the Caribbean (LC/SES. 38/11), Santiago, 2020.

[19] Marmot M, Allen J. J Epidemiol Community Health September 2020 Vol 74 No 9.

[20] A. V. Diez Roux Population Health in the Time of COVID-19: Confirmations and Revelations The Milbank Quarterly, Vol. 00, No. 0, 2020 (Pages 1-12).

[21] Joan Benach We Must Take Advantage of This Pandemic to Make a Radical Social Change: The Coronavirus as a Global Health, Inequality, and Eco-Social Problem. International Journal of Health Services DOI: 10.1177/0020731420946594.

[22] Editorial. The lancet. COVID-19 in Latin America: a humanitarian crisis. www.thelancet.com Vol 396 November 7, 20201463.

[23] FG. Benavidez. Workers' health and COVID-19 Arch Prev Risks Labor. 2020; 23 (2): 154-158. doi: 10.12961/aprl.2020.23.02.02.
[24] Mújica OJ, Moreno CM. From rhetoric to action: measuring health inequalities to "leave no one behind". Rev Panam Salud Publica. 2019; 43: e12. https://doi.org/10.26633/RPSP.2019.12.

[25] Helen Lambert, Jaideep Gupte, Helen Fletcher, Laura Hammond, Nicola Lowe, Mark Pelling, Neelam Raina, Tahrat Shahid, Kelsey Shanks COVID-19 as a global challenge: towards an inclusive and sustainable future July 20, 2020 https://doi.org/10.1016/S2542-5196(20)30168-6.

[26] Sridhar Devi. The evidence is clear: if countries act together, they can suppress Covid. The Guardian International edition. Sun 1 november 2020 https://www.theguardian.com/commentisfree/2020/nov/01/.

[27] Disha Shetty Rich Countries Reserve Billions of Covid-19 Vaccine Doses Even Before There Is One. Forbes 4 november 2020 https://www.forbes.com/sites/dishashetty/2020/11/04/richcountries-reserve-billions-of-covid-19-vaccine-doses-evenbefore-there-is-one/?sh=2b0ddd3b4e 17 .

[28] OCDE. Multinational enterprises in the global economy. Heavily debated but hardly measured. May 2018. https://www.oecd.org/industry/ind/MNEs-in-the-globaleconomy-policy-note.pdf.

[29] Regional Agreement on Access to Information, Public Participation and Access to Justice in Environmental Matters in Latin America and the Caribbean https://www.cepal.org/es/acuerdodeescazu.

[30] Ivan Illich. The convicencialidad in Obras reunidas I (Mexico: Fondo de Cultura Económica, 2006).

[31] Lebel J. Saud. An Ecosystem Approach 2005. Ottawa: Ed. Alfaomega International Center for Development Research.

[32] Joan Benach "There is a myopic look that blames contagions on individual responsibility, when the origin is in poverty" CTXT Èlia Pons (Diari de la Sanitat) 10/27/2020. 